\title{
Global innovation networks and university-firm interactions: an exploratory survey analysis*
}

\author{
Gustavo Britto ** \\ Ulisses Pereira dos Santos*** \\ Glenda Kruss**** \\ Eduardo Albuquerque ${ }^{* * * * *}$
}

Recebido: 22/01/2014 Versão Revisada (entregue): 16/06/2014 Aprovado: 24/06/2014

\begin{abstract}
The literature on Global Innovation Networks has contributed to identify changes in the innovation activities of multinational corporations. Although university-firm interactions are seen as an important factor for the emergence of GINs, their role has received limited attention. This paper aims to fill this gap in two ways. First, it carries out an exploratory analysis of an original survey dataset, of firms in three industrial sectors from nine developed and developing countries. Second, the paper analyses whether the role of universities in global innovation networks is related to national systems of innovation with varying degrees of maturity. Multiple correspondence analysis and a Probit model are used to establish the relevance of key factors in driving GINs. The results identify distinctive profiles constructed mainly according to firm characteristics, but reflecting country specific patterns of association. The
\end{abstract}

* Research for this paper was partially funded by the European Community's Seventh Framework Programme (Project INGINEUS, Grant Agreement No. 225368). The authors are also thankful for the financial support from CNPq and FAPEMIG. The authors alone are responsible for its contents an opinions herein.

** Universidade Federal de Minas Gerais (UFMG), Belo Horizonte (MG), Brasil. E-mail: gustavo@cedeplar.ufmg.br

*** Universidade Federal de Minas Gerais (UFMG), Belo Horizonte (MG), Brasil. E-mail: ulisses@cedeplar.ufmg.br

**** Human Sciences Research Council (HSRC), África do Sul. E-mail: gkruss@hsrc.ac.za

***** Universidade Federal de Minas Gerais (UFMG), Belo Horizonte (MG), Brasil. E-mail: albuquer@cedeplar.ufmg.br 
Probit model confirms that internationalization processes and the existence of local interactions substantially increase the probability of interactions with international institutions.

KEYwords | Global Innovation Networks; National Systems of Innovation; University-Firm Interaction; INGINEUS Survey

JEL-CODES | O30; O57

\section{Redes globais de inovação e interaçóes universidade-empresa: uma análise exploratória de dados}

\section{RESUMO}

A literatura sobre redes globais de inovação (GINs) vem contribuindo para a identificação de mudanças na atuação de corporaçôes multinacionais. Contudo, tal literatura ainda não explorou o papel das interaçôes universidade-empresa nesse contexto. Objetiva-se aqui suprir essa lacuna em duas frentes. Primeiro, é apresentada uma análise exploratória de um banco de dados original contendo informaçôes de firmas de nove países desenvolvidos e em desenvolvimento. Em segundo lugar, avalia-se a ligação entre a interação com universidades e a maturidade do sistema nacional de inovação. O método de análise de correspondência múltipla e um modelo Probit foram utilizados para avaliar os fatores-chave para as GINs. Os resultados identificam perfis diferenciados pelas características das firmas, mas que refletem padrões nacionais de associação. O modelo Probit confirma que a internacionalização produtiva e as interações locais aumentam a probabilidade de existência de interaçôes com instituições internacionais.

PALAVRAS-CHAVE | Redes Globais de Inovação; Sistemas Nacionais de Inovação; Interação Universidade-Empresa, Projeto INGINEUS

\section{Códigos JEL | O30; O57}




\section{Introduction}

Global innovation networks (GINs) are a new phenomenon in science and technology studies. The emergence of GINs, of a new geography of knowledge, holds out the promise of subverting traditional global knowledge hierarchies (ERNST, 2009; ERNST; NAUGHTON, 2008). ${ }^{1}$ As Ernst and Hart (2008) note, the global changes 'evoke optimism, even utopian visions' for sharing in economic growth. The research literature suggests that this promise may be realised in emerging economies, at least in specific sectors such as ICT and electronics. Multinational companies (MNCs) have offshored knowledge activities by establishing local innovation centres in China and India, contributing to form the hub of GINs, including outsourcing to local universities in the host country. These countries have two major attractions for Northern MNCs - very large markets, and large pools of qualified engineers and scientists - leading to the formation of GINs characterised by knowledge intensive forms of interaction between firms and universities.

Potential interaction with universities and public research institutes in a region or country is a key factor influencing the innovation strategies of MNCs, both in relation to the education and training of a pool of highly skilled knowledge workers or in relation to meeting R\&D needs through university-firm linkages. Global networks based on offshoring and outsourcing of MNCs' research, development and innovation activities from developed countries, to firms, universities and public research institutes in developing countries, offer the opportunity for technological spillovers, access to knowledge assets and learning that can strengthen developing countries' national systems of innovation (NSI). A related phenomenon is firms from developing countries investing in advanced economies. These firms build external knowledge networks in order to overcome the constraints of immature innovation systems, using the resulting global knowledge flows to strengthen local capabilities.

Such real world cases combine a wide variety of possible interactions between the main actors within an innovation network. In a recent attempt to untangle this web of relationships, Britto et al. (2013) propose a typology of GINs based on the literature on interaction between firms and universities, which is part of a broader literature on NSI, and on the literature on GINs, part of the literature on MNCs.

Despite the increasing recognition of the importance of GINs and the key role played by universities, empirical evidence is still elusive. Thus far, the evidence for GINs has tended to take the form of case studies in a limited range of sectors and

1 The benefits of globalization of production have been stressed in the context of global production networks by Henderson et al. (2002) and Ernst (2002). A conceptual discussion of GINs can be found in Chaminade (2009). 
countries. Even more limited is cross-country evidence encompassing characteristics of all the actors involved.

The paper aims to fill this gap in two ways. First, it carries out a rigorous exploratory analysis of international data. It draws on a large original survey of firms in three industrial sectors with varying degrees of technological intensity, from nine developed and developing countries (INGINEUS, 2011a). Second, it searches for international patterns of interactions to address the critical question: is the role of universities in global innovation networks related to the strategies of firms, and to NSI with varying degrees of maturity? The paper focuses on three factors to explore the data: the degree of internationalisation, the degree of innovative effort and the degree to which universities and public research institutes are sources of knowledge for firms.

To accomplish this task requires a two-step approach. First, the paper applies a Multiple Correspondence Analysis (MCA) method, a technique designed to search for patterns in large amounts of disparate, qualitative data. It evaluates how the firm characteristics critical to GIN formation relate to the existence of university-firm collaboration, both local and global. The existence of a relationship between the degree of maturity of NIS and GIN formation would imply distinct patterns of these dimensions across countries and sectors.

Secondly, and critically, the paper uses the MCA results to inform the estimation of a Probit model, by selecting the most relevant variables. The objective is to formally measure if the selected variables increase the probability of a firm interacting with universities abroad.

Such empirical evidence will contribute to the emerging research literature on the role of universities in the emergence of GINs. The paper is divided into five sections, apart from this introduction. Section two presents a review of the distinct literatures on GINs and on university-firm interactions, to demonstrate the theoretical gap and to highlight the importance of the nature of university-firm interactions in GIN formation. Section three provides a description of the original dataset built from the survey of firms, and describes the set of variables used for the MCA method. Section four presents the results of the MCA. Section five presents the results of the Probit model used to test the relationship between key variables relating to firms interactive activities. Concluding remarks on the evidence for shifting global knowledge relations are presented in section six. 


\section{Interactions with universities and GINs}

There is a gap between two strands of the innovation literature, each of which takes into account the significance of universities and MNCs, but fails to investigate the two together systematically. The first investigative line, led amongst others by Klevorick et al. (1995), Nelson (1993) and Cohen et al. (2002), focuses on the interactions between universities and firms. Within this strand, knowledge flows of MNCs have been investigated (NARIN et al., 1997). In general, this literature tends to investigate interactions within the boundaries of a single country, and does not consider the international dimension in depth.

In turn, the emerging literature on GINs does not investigate university-firm interaction adequately. Universities are identified as an important factor for the emergence of GINs (ERNST, 2006; UNCTAD, 2005; DUNNING; LUNDAN, 2008) but the precise nature of their role received limited attention.

This section evaluates how the literature on firm interaction with universities deals with the globalization of R\&D, and how the literature on GINs deals with the role of universities, in order to identify key dimensions for the analysis.

\subsection{The role of universities in the literature on GINs}

There is a largely implicit relationship assumed between GINs and universities in the literature on GINs. A taxonomy of GINs proposed by Ernst (2009) attributes a relatively minor role to links with universities, and these are largely implicit, drawing from previous formulations by Dunning (1995) and Kuemmerle (1997). A survey carried out by The Economist Intelligence Unit (2007) found that the majority of firms involved in GINs identified universities as the most important collaborative partners, ahead of customers, suppliers and even joint ventures. Another survey of firms in the United States and Western Europe found that the existence of universities with special scientific and engineering expertise is one of the most important determinants in the selection of sites for R\&D location, in both developed and developing economies (THURSBY; THURSBY, 2006). Further evidence of the importance of the globalization of industry-science relationships can be found in an OECD report (2008) that shows the various ways in which firms search for and identify new external sources of innovation, particularly from universities and research institutes. Kuemmerle (1997) identified foreign universities as frequent targets for "home base augmenting" foreign R\&D. Gompers and Lerner (2001) showed that 
corporate venture capital is often used to foster joint ventures and collaboration with universities in order to access new ideas for innovation in the face of declining internal R\&D. UNCTAD (2005) focused on strategic alliances as an indication of the increasing internationalization of R\&D. Asian-based MNCs are also found to search for foreign contacts with leading universities and research institutes based in the USA and Europe (ERNST; NAUGHTON, 2008).

This literature emphasises the significance of universities in the formation of GINs, but from a very limited perspective. The focus lies on firm strategy, rather than an investigation of the nature of interaction or the nature and role of universities in NSI.

\subsection{The role of international networks in the literature on interaction}

Ernst (2002) criticized the literature on the national system of innovation for neglect of the international dimension, a valid criticism. Nevertheless, early studies emphasized the relatively slower trend to globalize technology, vis-à-vis finance and production (CANTWELL, 1995; PATEL, 1995). A key subject of evolutionary studies - catch up processes - stresses the importance of international links and access to foreign knowledge and technology. In these processes, students were sent abroad, engineers hired to run new firms or start new faculties - some of the key strategies used to absorb knowledge from abroad (NELSON, 1993).

Other studies show how global changes impact the fate of NSIs (NELSON; WRIGHT, 1992). Studies of international alliances and cooperation have shown how connections between different NSIs are established (HAGEDOORN, 2002; OSTRY; NELSON, 1995). Pavitt (1991) demonstrated the importance of scientific infrastructure to attract foreign firms.

\subsection{Two main drivers and complex dynamics}

The two strands in the existing literature thus suggest that GINs have two main drivers that need to be investigated simultaneously. The first driver is led MNCs and their growing capabilities, technological and locational diversity, as they move across the world selecting locations and distributing productive and innovative labour (DUNNING; LUNDAN, 2008; CANTWELL, 2009). Second, the formation and growing complexity of NSI, especially in the developing world, is a process that goes far beyond the push of production towards new regions and sectors (FREEMAN, 
1988; LUNDVALL, 1988; NELSON, 1993). The formation of NSIs involves political forces that shape states and their autonomy, capabilities and public resources to generate and support their public knowledge institutions.

Therefore, there are two dynamics reshaping and reorganizing the international division of labour, related to both MNCs and NSI. The combination of these two drivers leads to a complex picture, where the nature of NSIs matters for the formation of global innovation networks, their main characteristics and the nature and scope of the international hierarchies established.

The importance of university-firm interactions as a key component of the larger process of international division of labour has been recognised recently by Britto et al. (2013), who argue that the formation of GINs is associated with varying degrees of university-firm interactions. The study introduced a framework of global interactions between firms and universities in an attempt to bridge the two strands of the literature. However, evidence for such patterns of interactions tends to rely on a case study approach. What remains to be found is evidence of more widespread connections amongst the characteristics described by the literature as key components of GINs, namely, internationalization (in their global reach), innovation and interactions (in their networked forms).

\subsection{A multitude of country and case studies}

The importance of university-firm interaction at the national and international levels has been extensively registered in the literature going as far back as Prager and Omenn (1980) (see also MANSFIELD; LEE, 1996). More recently, a new wave of country studies can be found, particularly in developing economies. Interaction within national boundaries that may involve MNC subsidiaries can be found in Suzigan et al. (2011), Lee et al. (2009) and Kruss et al. (2012).

OECD (2008) research on Japanese MNCs and their networks with universities illustrated a different set of possible connections between MNC headquarters, subsidiaries and universities. Azevedo (2009) and Dantas and Bell (2009; 2011) analysed a Brazilian state owned oil company that collaborates with 70 universities and research centers from advanced countries. De Campos (2006) investigated the relationship between MNCs location strategies and their subsidiary's universityfirm links. The role of universities as search mechanisms for local economies was emphasised by Evenson and Golling (2003). Eun et al. (2006) suggest that academic run enterprises are modes specific to the Chinese context of universities with 
stronger capabilities than firms. The variety of cases shows that over time, the roles of universities become more diverse (teaching and research in new areas, demands for advice for public policy) as universities' capabilities develop.

Although there is a multitude of such case and country studies in the literature, cross-country evidence of the formation of GINs is scant, as is the evaluation of the role played by university-firm interactions. Given the diversity of real world cases, the questions of how important universities are to GINs, and how their role relates to distinct levels of maturity of national innovation systems, remain to be answered. The next sections thus present our exercise aimed at filling this gap using a multi-country dataset. The data reflects customized questions focusing on the most important characteristics of GINs.

\section{Data and methodology}

\subsection{The survey}

The INGINEUS research project sought to evaluate the extent to which innovation takes place in global networks that spread through both developed and developing countries. A new dataset was created, based on a customised survey questionnaire, aimed at comparison of sectors across regions. Analysis of the dataset enables simultaneous investigation of how key components of GINs are related, and whether such relations are connected to varying levels of development. ${ }^{2}$

The survey was carried out between October 2009 and January 2010 in nine countries, including Norway, Sweden, Germany, Estonia and Denmark in the developed world, and Brazil, India, China, South Africa in the developing world. ${ }^{3}$ The selection of three focus sectors was based on the notion that the process of outsourcing knowledge-intensive activities as well as the emergence of knowledge creating activities could be spreading from more advanced to more traditional sectors of developing economies. By design, each country was assigned a single sector (ICT, automotive or agroprocessing), based on its importance in their national and regional contexts. In order to enable the identification of distinct realities in the

2 Countrywide industry surveys were used as the source of the sample to which questionnaires were sent. For complete information of the INGINEUS survey design and full set of results, see INGINEUS (2011b; 2011c).

3 The data was collected through an online questionnaire. In some countries face-to-face or telephone interviews were used. Given the concern with the outsourcing of R\&D from Europe to other regions, participating countries selected included eastern and western European countries as well as major emerging economies. 
emergence of GINs, each sector was covered by at least a developed and a developing country. Agro-processing was included in South Africa and Denmark, automotive in Brazil, Germany and a small sample from Sweden, and ICT was the subject in India, China, Sweden, Norway and Estonia. Whereas in developed countries the surveys were national, in developing countries the surveys were regional, due to both geographical size and population spread. ${ }^{4}$

Following ensuring the compatibility of sector codes, 1,215 responses were obtained (Table 1). The table provides information on the response rates obtained. Although the response rates appear to be low, the absolute number is reasonable per country and very good on the aggregate, yielding a suitable number of observations for the methodology used.

\section{TABLE 1}

INGINEUS survey results breakdown and response rates Selected countries - 2009/2010

\begin{tabular}{lcccc}
\hline Countries & ICT & Auto & Agro \\
\hline Denmark & & & 49 \\
Estonia & 17 & & $(23.3 \%)$ \\
Germany & $(14 \%)$ & & \\
Norway & & $(5.5 \%)$ & \\
Sweden & 181 & & \\
& $(11.9 \%)$ & 24 & \\
Brazil & 171 & $(14.3)$ & \\
& $(10.3)$ & 69 & \\
China & & $(28.6 \%)$ & \\
& & & \\
India & 243 & & \\
South Africa & $(2.7 \%)$ & & 133 \\
Total sector & 324 & & \\
\hline
\end{tabular}

Source: Ingineus (2011c).

4 In Brazil the survey was restricted to the state of Minas Gerais. China includes Beijing and Shenzen. In India, Bangalore, Delhi, Mumbai, Pune, Trivandrum, Hyderabad and Kochi were targeted. 
TABLE 2

Survey questions, variables, categories and response rates (1)

Selected countries - 2009/2010

\begin{tabular}{|c|c|c|}
\hline Variables & Options and codes & $\%$ \\
\hline Country & $\begin{array}{l}\text { Denmark (DNK), Estonia (EST), Germany } \\
\text { (GER), Norway (NOR), Sweden (SWE), } \\
\text { Brazil (BRA), China (CHN), India (IND) } \\
\text { South Africa (ZAF) }\end{array}$ & \\
\hline $\mathrm{R} \& \mathrm{D}:$ & Yes $(\mathrm{R} \& \mathrm{D})$ & 44.29 \\
\hline Do you have significant R\&D activity? & No $(R \& D)$ & 55.71 \\
\hline Internationalization: & Yes (INTL) & 70.26 \\
\hline $\begin{array}{l}\text { Regarding internationalization, does } \\
\text { your firm offshore (or has your firm } \\
\text { offshored) production or any R\&D } \\
\text { activities? }\end{array}$ & No (N-INTL) & 29.74 \\
\hline $\begin{array}{l}\text { Informal interaction with foreign } \\
\text { universities and research centers }\end{array}$ & $\begin{array}{l}\text { Yes (UNI-INF) } \\
\text { No (N-UNI-INF) }\end{array}$ & $\begin{array}{r}93.99 \\
6.01 \\
\end{array}$ \\
\hline $\begin{array}{l}\text { Formal interaction with foreign } \\
\text { universities and research centers }\end{array}$ & $\begin{array}{l}\text { Yes (UNI-FOR) } \\
\text { No (N-UNI-FOR) }\end{array}$ & $\begin{array}{l}85.02 \\
14.98 \\
\end{array}$ \\
\hline $\begin{array}{l}\text { Interaction with local universities and } \\
\text { research centers }\end{array}$ & $\begin{array}{l}\text { Yes (LUNI-INV) } \\
\text { No (N-LUNI-INV) }\end{array}$ & $\begin{array}{l}68.97 \\
31.03 \\
\end{array}$ \\
\hline Type of Enterprise & $\begin{array}{l}\text { 1. Standalone (STD) } \\
\text { 2. MNC Subsidiary (MNC-S) } \\
\text { 3. MNC Headquarters (MNC-HQ) }\end{array}$ & $\begin{array}{l}64.53 \\
22.91 \\
12.57\end{array}$ \\
\hline $\begin{array}{l}\text { Main source of Technology: } \\
\text { 1. We produce most technological inputs } \\
\text { in-house. } 2 \text {. We buy most of our inputs } \\
\text { from other branches of our own MNC. } \\
\text { 3. We buy most of our technological } \\
\text { inputs from non-MNC firms. } 4 \text {. We buy } \\
\text { most of our inputs from MNCs with } \\
\text { which we are not formally connected. } \\
5 . \text { We buy most of our inputs from } \\
\text { public-sector organizations, e.g. research } \\
\text { institutes, universities. }\end{array}$ & $\begin{array}{l}\text { 1. (INHOUSE) } \\
\text { 2. (BRANCH) } \\
\text { 3. (LOCAL) } \\
\text { 4. (MNC) }\end{array}$ & $\begin{array}{l}60.02 \\
10.60 \\
11.96 \\
15.18\end{array}$ \\
\hline
\end{tabular}

Source: Ingineus (2011b; 2011c)

(1) Further descriptive statistics are given in Table 1 in the Appendix..

The selection of items from the survey for the MCA is summarised in Table $2^{5}$. Apart from the country in which the firm is based, the choice of variables was informed by the three core features associated with the emergence of GINs,

5 Questions, indicators and typology follow closely the language from National Innovation Surveys. 
highlighted in our review. The first is internationalisation, or the degree to which the firm has a global reach. The two proxy variables selected are firm ownership and offshoring of R\&D. The second feature is the innovativeness of the firm, measured by the variable of R\&D. Third, to investigate the degree of interaction or networks, two proxy measures were adopted: the sources of technology and different types of interaction. ${ }^{6}$ It is to be expected that some of these variables are important to more than one of the three dimensions of a GIN.

\subsection{Multiple Correspondence Analysis Method}

The MCA method was used both as a tool for exploratory data analysis and to select of variables for the second exercise, to test relationships. The number of observations enables the search for patterns of association between the selected variables, which can define distinct profiles. ${ }^{7}$

MCA is a multivariate statistical method that enables testing for association between two or more categorical variables, as an alternative method to Principal Component Analysis (LE ROUX; ROUANET, 2010; EZZRARY; VERME, 2012). ${ }^{8}$ The technique transforms categorical information available in a table into a correspondence graph that allows us to evaluate their association, in order to identify distinct profiles (GREENACRE, 2005). The method generates a smaller number of dimensions (usually two) that summarize the information in a set of variables. The association between the categories of the variables analysed is used for the identification of profiles into which sample elements fit.

Besides the active variables used in the computation of the new dimensions, supplementary variables can be used. These variables do not influence the calculation, but are useful to add additional information for analysis of the profiles obtained. In the exercise carried out in this paper, the variable 'country' was used as such a supplementary variable.

The objective of the first exercise is to search for distinctive patterns in the association between different types of interaction with universities, and the firm characteristics that are closely related to GINs.

6 In the case of interactions with universities, local means both in the same country and in the same region. This is relevant for European countries (INGINEUS, 2011b: p.19).

7 Despite its relative novelty in economics, other studies such as Tether and Tajar (2008) use MCA on survey data to identify different patterns of innovation in Europe.

8 These methods are similar in terms of use of geometric analysis, even though using different types of data. They are both data exploration techniques that are used to search for correlation patterns across sets of variables. While continuous data is summarized in principal components by the PCA, categorical data is summarized in dimensions by MCA (EZZRARY; VERME, 2012). 


\section{Results and Discussion}

The results of the MCA are divided into two sets. The first set presents the results for the full sample, where the objective is to test for the existence of patterns amongst all the selected variables. The countries associated with each profile can be identified. The placement of a country in a profile does not mean that all firms do not possess the variables included in that profile, but only that the specific pattern is not prevalent for that country.

To circumvent bias and to provide a clear comparison between the countries associated with a specific sector, the second set of results is decomposed by sector.

\subsection{Patterns in the Full Sample}

As a basis for analysing the MCA results, Table 3 shows the percentage of surveyed firms that reported interactions with local and foreign universities. The highest percentages of interactive firms are reported in India and Germany, and with foreign institutions in India. In contrast, Brazil, Denmark and Estonia show smaller shares of interactive firms. Note that $20 \%$ of the firms in the overall sample indicated links with foreign universities. Since the share of interactive firms is substantial, the next task is to identify patterns in the emergence of GINs related to these interactions.

TABLE 3

Percentage of surveyed firms that have interactions with local and foreign universities

Selected countries - 2009/2010

\begin{tabular}{lcc}
\hline Countries & Local Univ. & Foreign Univ. \\
\hline Denmark & 4.0 & 4.0 \\
Estonia & 12.0 & 0.0 \\
Germany & 45.0 & 17.0 \\
Norway & 24.0 & 8.0 \\
Sweden & 34.0 & 16.0 \\
Brazil & 10.0 & 16.0 \\
China & 20.0 & 14.0 \\
India & 47.0 & 40.0 \\
South Africa & 37.0 & 21.0 \\
Total & $\mathbf{3 1 . 0}$ & $\mathbf{2 0 . 0}$ \\
\hline
\end{tabular}

Source: Ingineus (2011b; 2011c) 
Table 4 shows the quality index of the categories for the analyzed variables in the MCA analysis, and the contribution of each one to the two main dimensions obtained. Only the variable 'source of technology' is poorly represented on the chart, but the categories may be used in the interpretation of the results, with this proviso.

The contributions index identifies categories of the variables that are more important for explaining the variability of the dimensions. Categories with a contribution larger than the average (here $100 / 18=5.55 \%$ ) can be considered important (LE ROUX; ROUANET, 2010).

TABLE 4

MCA for the full sample: main outputs

\begin{tabular}{|c|c|c|c|c|c|}
\hline \multirow[b]{2}{*}{ Variables } & \multirow[b]{2}{*}{ Categories } & \multirow[b]{2}{*}{ Description } & \multirow[b]{2}{*}{ Quality } & \multicolumn{2}{|c|}{ Contribution } \\
\hline & & & & $\begin{array}{c}\text { Dimension } \\
1 \\
\end{array}$ & $\begin{array}{c}\text { Dimension } \\
2 \\
\end{array}$ \\
\hline \multirow{3}{*}{ Type of enterprise } & 1 & Standalone & 0,78 & 0,057 & 0,041 \\
\hline & 2 & MNC Subsidiary & 0,69 & 0,048 & 0,254 \\
\hline & 3 & MNC HQ & 0,893 & 0,055 & 0,046 \\
\hline \multirow{2}{*}{$\mathrm{R} \& \mathrm{D}$} & 1 & No & 0,76 & 0,099 & 0,033 \\
\hline & 3 & Yes & 0,76 & 0,074 & 0,025 \\
\hline \multirow{5}{*}{$\begin{array}{l}\text { Source of } \\
\text { Technology }\end{array}$} & 1 & In house & 0,224 & 0 & 0,063 \\
\hline & 2 & $\begin{array}{l}\text { Branches of the } \\
\text { own MNC }\end{array}$ & 0,455 & 0,003 & 0,229 \\
\hline & 3 & Non MNCs & 0,616 & 0,017 & 0,021 \\
\hline & 4 & $\begin{array}{c}\text { Non connected } \\
\text { MNCs }\end{array}$ & 0,338 & 0,005 & 0,002 \\
\hline & 5 & Universities & 0,282 & 0,002 & 0,034 \\
\hline \multirow{2}{*}{ Internationalization } & 1 & No & 0,836 & 0,081 & 0,003 \\
\hline & 3 & Yes & 0,836 & 0,186 & 0,006 \\
\hline \multirow{2}{*}{$\begin{array}{l}\text { Formal int. foreign } \\
\text { univ. }\end{array}$} & 1 & No & 0,792 & 0,036 & 0,008 \\
\hline & 3 & Yes & 0,792 & 0,166 & 0,035 \\
\hline \multirow{2}{*}{$\begin{array}{l}\text { Informal int. } \\
\text { foreign univ. }\end{array}$} & 1 & No & 0,603 & 0,002 & 0,009 \\
\hline & 3 & Yes & 0,603 & 0,022 & 0,125 \\
\hline \multirow{2}{*}{$\begin{array}{l}\text { Interaction local } \\
\text { univ. }\end{array}$} & 1 & No & 0,765 & 0,055 & 0,025 \\
\hline & 3 & Yes & 0,765 & 0,093 & 0,041 \\
\hline
\end{tabular}

Source: Ingineus (2011b; 2011c)

Dimension 1 is defined by the categories $R \& D$, internationalization, formal interactions with foreign universities and interactions with local universities (Table 
4). The type of enterprise also contributes. Thus, Dimension 1(x-axis) defines the innovative effort of firms.

Dimension 2 (y-axis) is defined by the categories MNC subsidiary, informal interactions with foreign universities, and the source of technology being other branches of own MNC. Developing technology in-house also contributes to define this dimension. Thus Dimension 2 is defined in terms of the features of MNC subsidiaries.

Graph 1 below depicts the correspondence chart from the MCA for all nine countries and sectors. Together the two axes account for almost three quarters of the overall variance, indicating a very good fit for the analysis. Each point on the chart receives a code representing the variable category (see Table 2 above).

\section{GRAPH 1}

Multiple correspondence analysis chart for the full sample

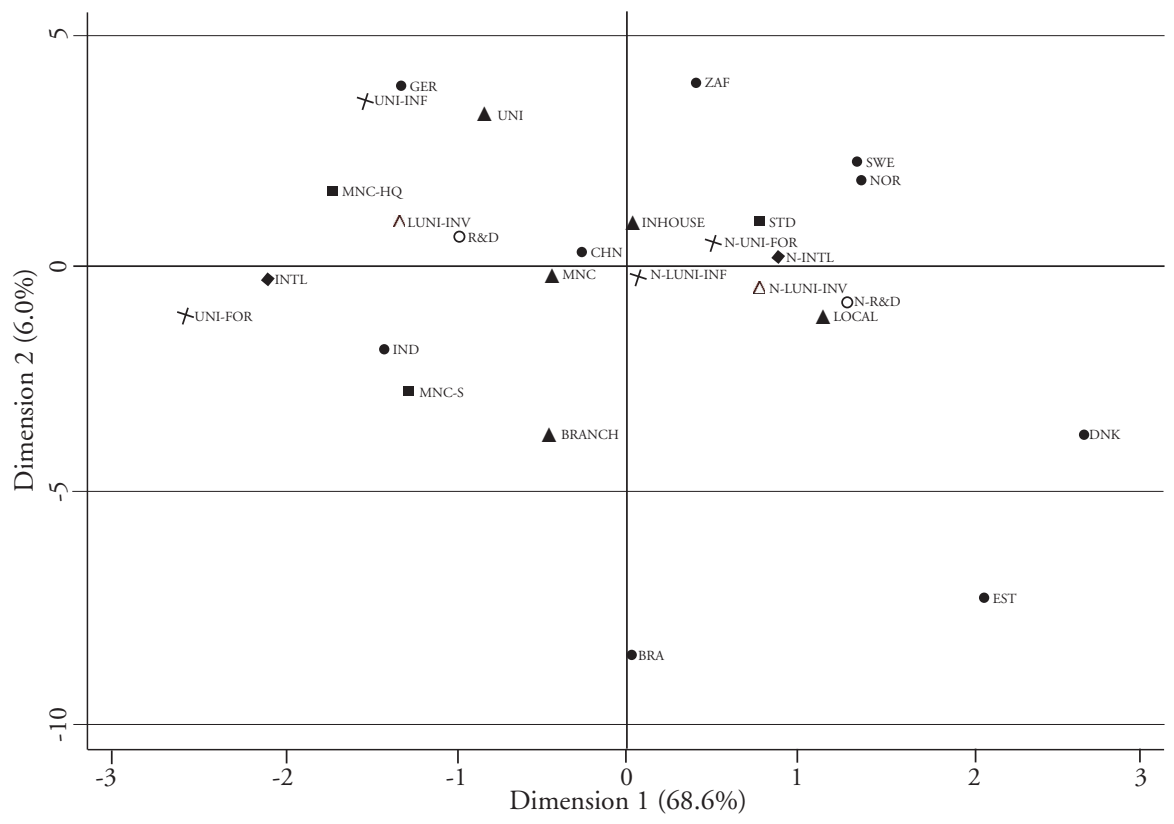

Supplementary (passive) variable : Country

Coordinates in standard normalization

Source: Ingineus (2011c).

A profile is defined by a set of variables clustered together in one of the quadrants. Dimension 1 separates dynamic innovative effort on its left-hand side (negative segment) and the absence of such effort on its right-hand side (positive segment). In most cases, the profiles can be identified and interpreted quite easily, 
given that a group of active variables is clustered near one of the supplementary country variables. Four distinct profiles are identified and analysed moving clockwise from the upper right hand quadrant.

The profiles located in the first and second quadrants (related to the absence of interactivity) reflect predominantly low innovative characteristics. The first discernible profile includes South Africa, Sweden and Norway, marked by the presence of local companies, with low degrees of internationalization, and lack of formal interactions with foreign universities. The development of technological outputs at home is the most important source of technology for the firms. The characteristics indicate primarily smaller scale enterprises focused on local markets, without a formal R\&D structure, that manage to meet their technological demands on their own. The close position of Sweden and Norway may reflect their similarities in terms of both NSI and industrial sector, ICT. Although the data for Sweden shows a reasonable number of interactive firms, they do not share the other characteristics that are represented by the most interactive profiles. South Africa's position reflects a weaker relationship with the variables in the profile. The results show commonalities amongst the patterns of interaction for firms in these countries, irrespective of sector.

Profile 2 in the second quadrant is also characterised by a pattern of low innovative effort. Its features are a relative lack of local $R \& D$, and a lack of interactions with local and foreign universities. These firms tend to buy technological inputs produced by non-MNC companies. The countries - Denmark, Estonia and Brazil - are relatively distant from the categories that characterize the profile, but fit best with Profile 2. Unlike Profile 1, there is no tendency toward innovative effort. This trend may be associated particularly with the immature NSIs in Brazil and Estonia, and with the specificities of the economic activity surveyed in the case of Denmark, the agro-processing sector.

In contrast, the more dynamic profiles in terms of innovative effort are displayed in the negative segment of Dimension 1. Profile 3 in the bottom left-hand quadrant is characterized by the existence of subsidiaries of MNCs and by the acquisition of technology from other branches of the same MNC as well as other MNCs. These companies reported that they offshore production and R\&D activities. The most closely associated country is India, consistent with the fact that the country has been the recipient of large sums of investment in the ICT sector in recent decades.

This profile also reflects the presence of formal interactions between firms and foreign universities. Given the presence of MNC subsidiaries, it is possible to argue that these interactions are directed to the firms' home country institutions in 
most of the cases. However, even though most of the firms are MNCs subsidiaries, working in large and emergent markets such as the Indian one, they still rely on the acquisition of technological inputs primarily from other branches of the MNC or other MNCs.

Finally, in the fourth quadrant of Graph 1, Profile 4 can be clearly distinguished, clustering features that are usually associated with more advanced NSIs. The categories that indicate significant R\&D activities are close to those that indicate informal interaction with foreign universities, and interactions with local universities. There are two countries associated with this pattern of responses, Germany and China. Three other aspects of this profile are worth noting. The first is that firms tend to acquire most of their technological inputs from research institutes and universities, a characteristic that reinforces its interactive status. The second aspect is the predominance of MNC headquarters, which indicates that MNCs tend to concentrate their interactions more strongly at their headquarters. Finally, China is in this profile, even though it is far from the other variables, indicating that the dynamics of innovation in China are closer to that of Germany than to other developing countries. This pattern highlights the significance of analysis of the dynamics of firms in specific sectors.

The combined analysis of all profiles provides key empirical evidence for the association between significant firm R\&D activities, procurement of technology from universities and research institutions, and interaction with local and foreign universities. The characteristics observed in profile 4 give rise to complex forms of GINs. What is more, the level of complexity increases as linkages with universities, local and foreign, become more frequent.

Given the relatively high number of responses obtained for each country, the broad patterns described may hide sector specific trends and differences. Hence, the next sections proceed to apply the MCA to each of the three sectors covered in the survey.

\subsection{Automotive sector}

The sample for the automotive sector included 146 firms from Germany, Brazil, and Sweden. ${ }^{9}$

9 Readers should be reminded the sample of firms in Brazil stems from the automotive sector in one state. Therefore it is neither representative of the country or the sector. 
GRAPH 2

Multiple correspondence analysis: automotive sector

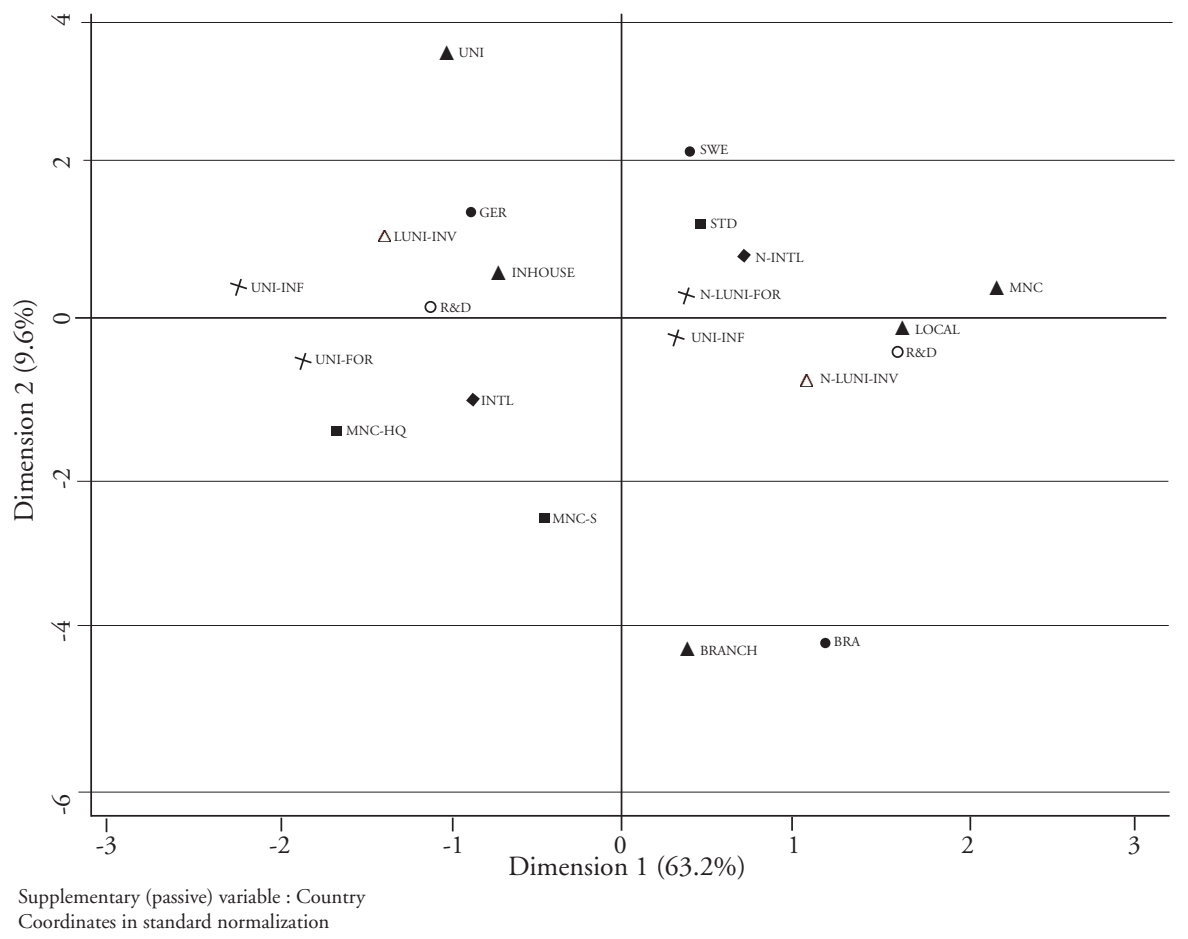

Source: Ingineus (2011c).

For the profile in the first quadrant, identified by Sweden, all the variables are located close to the positive part of the vertical axis. The specific variables suggest a pattern of smaller scale automotive companies with a small international reach, the lack of interactions with foreign universities and the procurement of new technology inputs from MNCs with which the firms is not associated.

The second profile, identified by the presence of Brazilian firms, is marked by the absence of interactions between firms and universities. Automotive firms acquire technological inputs from other branches of the MNC and from local companies. The absence of R\&D activities suggests the profile is marked by low innovative effort.

In contrast, the fourth profile associated with Germany clusters the categories of variables that indicate a more mature NSI: regular R\&D activities, interactions between firms and local universities, informal interactions with foreign universities, universities and research institutes as the main sources of knowledge, together with the nature of the firm itself. 
The third quadrant reflects the association of a set of variables regardless of the supplementary variable 'country'. They are frequently found together in different countries, but are not predominant. This profile is associated with firms that are headquarters and subsidiaries of MNCs, in other words, global automotive companies that have formal relationships with foreign universities, and processes of internationalization of $R \& D$ activities and production.

\subsection{Agro-processing sector}

The MCA exercise for the agro-processing sector displays distinct patterns for 133 observations from South Africa and Denmark, as well as two other profiles that are not country specific (Graph 3).

In the fourth quadrant, South African firms are associated with a profile characterised by positive responses to variables that capture interactions. Companies have their main sources of technology in other MNCs with which they are not formally connected, and have significant $\mathrm{R} \& \mathrm{D}$. This profile reflects a strong innovative tendency in the agro-processing firms surveyed in South Africa, indicating sectoral technological efforts. Such a profile was not clearly visible in the analysis of the full sample, demonstrating how sectoral analysis allows the observation of differences in innovative potential and dynamics.

Danish companies in contrast, form a profile characterised by the lack of informal interaction with foreign universities, or any kind of interaction with local universities. Companies are more likely to purchase technology from other local companies. The in-house development of technology but the absence of formal $\mathrm{R} \& \mathrm{D}$ activities is also a feature.

Graph 3 also depicts two clusters of variables related to types of enterprise rather than a specific country, indicating minority trends. The first 'quasi-profile', located in quadrant one, aggregates local agro-processing companies, and is associated with a lack of internationalization. This quasi-profile is very close to the Danish profile. Thus even though they are in different quadrants, the firms in both profiles have very similar features, according to Dimension 1 specially. The second 'quasi-profile', in the third quadrant, is characterised by MNC subsidiaries. This type of firm is more likely to have outsourced $R \& D$ and production activities, and the main source of technological inputs is other branches of the MNC with which they are associated. 
GRAPH 3

Multiple correspondence analysis: Agro-processing sector

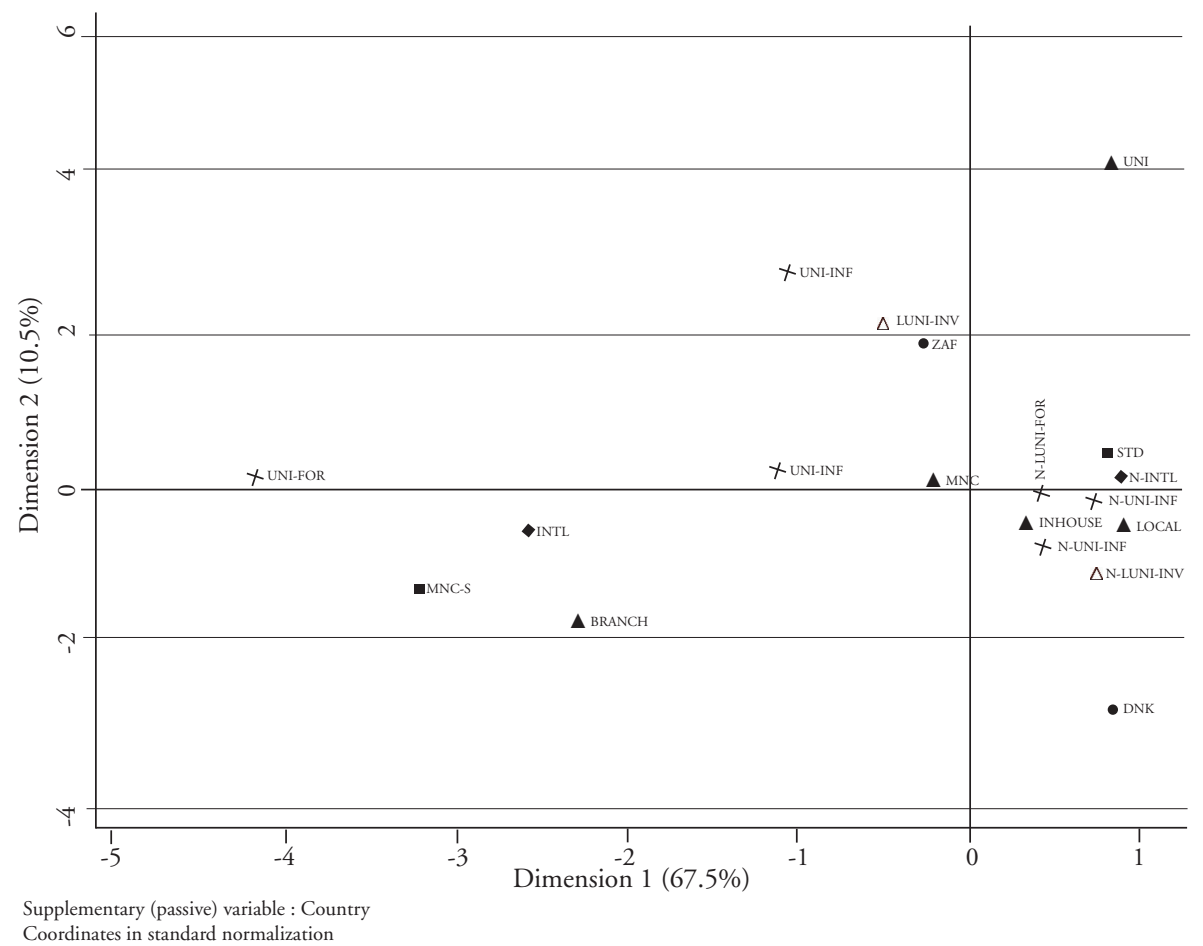

Source: Ingineus (2011c).

\subsection{Information and communication technology sector}

The analysis for the ICT sector yields three country specific profiles (Graph 4). In the first quadrant the Nordic countries, Sweden and Norway, form a profile characterized by the presence of local companies, and the absence of internationalization and formal interactions with foreign universities. There is a tendency to develop technology in house as the main source of new knowledge. The predominance of local firms in the sample for each of these countries may indicate a situation similar to that reported by Narula and Guimón (2010), when studying MNCs from peripheral eastern European countries. They found that local firms experienced significant difficulties in building networks with MNCs in high value added activities.

A country independent quasi-profile associated with MNC headquarters is found in the fourth quadrant, associated with the existence of R\&D activities, interactions with local universities and informal interactions with foreign universities. 
Thus, the most dynamic companies form a specific, country independent profile that has characteristics of large, highly networked MNCs.

The Chinese indicator on the chart is not defined by Dimension 1 at all, but only by Dimension 2, at an intermediary point between the two other profiles. China has contrasting features to the other two profiles located in the negative segment of Dimension 2, characterized by the prevalence of the purchase of technology from other MNCs, and interactions between firms and local and foreign universities.

\section{GRAPH 4}

Multiple correspondence analysis: ICT Sector

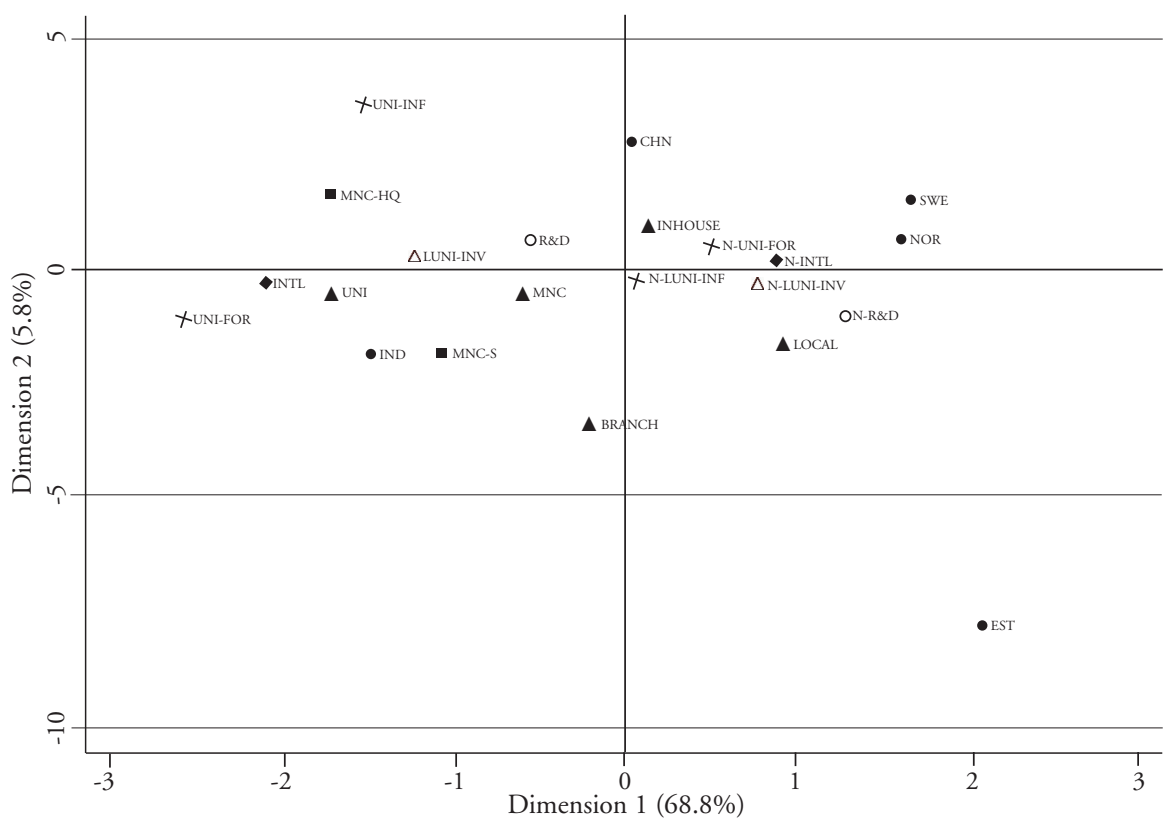

Supplementary (passive) variable : Country

Coordinates in standard normalization

Source: Ingineus (2011c).

A profile associated with companies located in India is observed in the third quadrant. The main characteristic is the predominance of subsidiaries of MNCs, formal interactions with foreign universities and the existence of processes of offshoring of $\mathrm{R} \& \mathrm{D}$ and production activities. Three sources of knowledge are associated with this profile: other branches of the MNC, other MNCs and universities and research institutions. The sectoral analysis reinforces the interactive tendency observed in the full sample analysis. 
Finally in the second quadrant there is another low innovative profile, marked by the presence of Estonia, even it is located at a distance from the other variables.

\section{Econometric analysis}

Having established distinctive patterns of association between variables for both the full sample and each sector using the MCA, a Probit model ${ }^{10}$ was estimated to investigate connections between university-firm interactions and variables associated with the emergence of GINs. ${ }^{11}$

The dependent variable is interaction with foreign universities and research institutions (yes $=1$, no $=0$ ), which was obtained from the variables Formal and Informal Interactions with Foreign Universities and Research Institutions. ${ }^{12}$ The model uses as independent variables the ones that presented quality index higher than 0.5 , how is displayed in Table $4 .{ }^{13}$

The estimated results for 990 observations are presented in Table 5. All the coefficients were significant at $10 \%$, and only the coefficient for the variable R\&D was not significant at $1 \%$ or $5 \%$. All coefficients have the expected signs, indicating that the independent variables increase the probability of the existence of interactions between the firms and foreign universities.

The results reinforce the patterns suggested by the MCA analysis. A closer view of the coefficients suggests that 'internationalization processes' and the existence of 'local interactions' have the largest marginal effects on average, increasing the probability of interactions outside the country. This suggests that for the interactive profiles, the companies that offshored activities are more likely to be linked with foreign research institutions, as well as the firms that build relationships with local universities.

The average marginal effects of the coefficients show that the existence of local interactions improves the probability of interactions with foreign universities by $20 \%$ and internationalization processes by $19 \%$. These are thus the most important firm

10 Similar methodologies for different datasets can be found in Lorenz (1999) and Levy et al. (2009).

11 Probit is an econometric model with qualitative dependent variable ( $y=0, y=1)$ that allows testing effects of the unitary variation in an explanatory variable $\mathrm{x}$ over the probability of $\mathrm{y}=1$ (success). The estimated Probit model is given by: $\operatorname{Pr}($ foreign_interactions $\left.=1 l x_{i}\right)=\Phi\left(x_{i}^{\prime} \beta\right)$, where $\Phi$ is the cumulative normal distribution, $\mathrm{X}$ the set of explanatory variables, and the coefficients $\beta$ are estimated by the Maximum Likelihood method (Greene 2003).

12 The correlation coefficients for the variables are displayed in Table 2 in the Appendix of this paper.

13 According to this criterion, which is a more flexible version of the one presented by Le Roux and Rouanet (2010), the variable Source of Technology could not be used as an independent variable. 
characteristics for the establishment of international innovation networks, according to the dataset. The variables $M N C$ and R\&D have smaller average marginal effects, improving the probability of the interactions with foreign universities by $8 \%$ and $4 \%$, respectively.

TABLE 5

Econometric Probit model: interactions with foreign universities

\begin{tabular}{lcccc}
\hline Variable & Coefficient & P-Value & Average Marginal effects \\
\hline MNC & 0,325 & 0,001 & 0,081 \\
Internationalization & 0,756 & 0,000 & 0,189 \\
R\&D & 0,184 & 0,076 & 0,046 \\
Local interactions & 0,802 & 0,000 & 0,200 \\
Constant & $-1,587$ & 0,000 & \\
\hline Pseudo R2 & 0,189 & & \\
Number of obs. & 990 & & \\
Log likelihood & $-442,007$ & & \\
LR chi2(4) & 205,740 & & \\
\hline
\end{tabular}

Source: Ingineus (2011c).

\section{Conclusion}

The use of the MCA method allowed identification of distinctive profiles for both the full and sector-specific samples that reflect country specific patterns of association.

The analysis of the full sample reflected distinctive patterns for countries at different levels of development. The profile associated with Germany, and to a lesser degree with China, reflected a pattern of significant R\&D activities with interactions with local and foreign universities. Firms in these regions acquire most of their technological inputs from universities and are primarily MNC headquarters. The contrasting profile associated with Brazil, Estonia and Denmark was marked by weak innovative activity, lack of interactions with local and foreign universities, absence of R\&D activities and procurement of technological inputs from other companies. Taken together, these profiles demonstrate a close association between levels of development, university-firm interactions and firms' innovative effort. 
Norway, Sweden and South Africa formed a profile that also suggests a noninteractive pattern, marked by the presence of local companies, lack of internationalization processes, no significant R\&D, and in-house development of new knowledge. It reflects firms with less sophisticated technologies that exercise internal technological effort. Finally, India is located in the interactive quadrant, an intermediary profile that shows the presence of MNC subsidiaries and formal interactions with foreign universities. Dependence on the procurement of technological inputs from other branches of the MNC or other MNCs is a significant feature of this profile.

It is important to reiterate that this analysis is indicative. The intent is not to classify countries in a definitive way, as either interactive or non-interactive. The analysis indicates which countries are closer to the set of characteristics that drive interactivity with internal and foreign universities, for the data in the sample - a first attempt to provide large scale data on the role of university-firm interactions in driving the emergence of GINs. This exercise helped to identify the countries in which firms are more likely to enter GINs. Germany, India and China are the best examples confirming trends in the research literature based on case studies.

The sectoral analyses broadly confirmed the trends identified for the full sample, particularly in the automotive sector. The patterns suggest that local characteristics are important in the establishment of profiles. The location of Germany and Brazil in contrasting profiles, both with firms in the automotive sector, or India and Sweden for ICT, is indicative of this trend.

The exploratory method allowed the identification of a peculiar pattern of responses yielding quasi-profiles that could not be linked with any specific country, particularly in the automotive and ICT sectors. Taken individually, they indicate that a minority of firms in each sector with a higher degree of internationalisation tended to have links with universities or other foreign partners more frequently. Taken together, these 'autonomous' interactive profiles form a significant group of companies, in terms of internationalisation, innovation and networking. Significantly, the quasi- profiles are formed by specific firms that are either subsidiaries or headquarters of MNCs, which present distinct patterns of responses in comparison with all the other firms. This finding may be interpreted as original empirical evidence for the emergence of GINs, which have different configurations depending on their sector and country location. In all cases, the presence of MNCs and of interactions with universities, are fundamental ingredients. 
Hence, the analysis contributes evidence to shed light on at least two relevant issues in the literature. First, the pattern of autonomous profiles represents emergent GINs in which university-firm interactions are always present. It provides empirical evidence that helps to bridge the two strands of literature, on the nature of university-firm interactions in the context of global innovation networks.

Second, the MCA analysis suggests that there is a case to be made for the influence of the level of development of NSIs. Only three countries, Germany, China and India, were located in profiles that are at the same time innovative, connected with other partners, and show a degree of internationalisation. Germany, it is widely accepted, has a very well-developed NSI, China is a country undergoing fast economic growth, and India has a large pool of qualified talent for the ICT sector specifically. While Germany is recognized as one of the world's economic and technological leaders, India and China are potential leaders in next few decades, as is Brazil. Nevertheless the MCA analysis for this sample shows that the automotive sector in Brazil is still in an inferior position, confirming the view in the literature that its NSI is immature (ALBUQUERQUE, 1999). These results add voice to the suggestion that the promise of GINs to subvert traditional knowledge hierarchies may be unevenly distributed (ERNST; HART, 2008), and the development possibilities may be overestimated.

The Probit model shows that the most important variables for the construction of the MCA profiles contribute positively to increase the probability of interaction with foreign universities. The model also shows that internationalization processes and the existence of local interactions are the firm characteristics that tend to contribute most strongly to the probability of interactions with international institutions, compared with the other characteristics observed.

Of course, the interpretations apply only to this specific sample of companies in their respective sectors and countries. Even with the relatively high number of respondents, the survey is not representative of each sector in the country, with the exception of Sweden. The broad trends highlighted by these profiles can be further refined through case studies and larger surveys, in terms of sample size, number of countries and sectors. Another fruitful avenue of research is combined analysis of the survey, Community Innovation Surveys and patent data. 


\section{References}

ALBUQUERQUE, E. National Systems of Innovation and Non-OECD Countries: notes about a rudimentary and tentative typology. Brazilian Journal of Political Economy, v. 19, n. 4, p. 35-54, 1999.

AZEVEDO, J. G. Petrobrás - From Lobato to Tupi: 70 years of results and challenges for people and technology. In: 11th International Congress of the Brazilian Geophysical Society. Salvador, 2009.

BRITTO, G.; CAMARGO, O. S.; KRUSS, G.; ALBUQUERQUE, E. M. Global interactions between firms and universities. Innovation and Development, v. 3, p. 71-87, 2013.

CANTWELL, J. The globalisation of technology: what remains of the product cycle model? Cambridge Journal of Economics, n. 19, p. 155-155, 1995.

. Innovation and information technology in the MNE. In: RUGMAN, A. M. (Ed.). The Oxford handbook of international business. Oxford: Oxford University Press, 2009, p. 417-446.

CAVES, R. E. Multinational enterprise and economic analysis. Cambridge: Cambridge University Press, 1996.

CHAMINADE, C. On the concept of global innovation networks.. Sweden: Lund University, 2009 (CIRCLE Eletronic Working Papers, 2009/05).

COHEN, W. M.; NELSON, R. R.; WALSH, J. P. Links and impacts: the influence of public research on industrial R\&D. Management Science, v. 48, n. 2, p. 1-23, 2002.

DANTAS, E.; BELL, M. Latecomer firms and the emergence and development of knowledge networks: The case of Petrobrás in Brazil. Research Policy, v. 38, n. 5, p. 829-844, 2009.

. The co-evolution of firm-centered knowledge networks and capabilities in late industrializing countries: the case of Petrobras in the offshore oil innovation system in Brazil. World Development, v. 39, n. 9, p. 1570-1591, 2011.

DE CAMPOS, A. L. University-industry in late-industrialising countries: a study of Unilever Brazil. Saarbruck: LAP, 2006.

DUNNING, J. H. Multinational enterprises and the global economy. Workingham: Addison-Wesley, 1995.

DUNNING, J. H.; LUNDAN, S. M. Multinational enterprises and the global economy. Edward Elgar Publishing, 2008. 
DUTRÉNIT, G. Introduction to special issue - Interactions between public research organisations and industry in Latin America: a study on channels and benefits from the perspective of firms and researchers. Science and Public Policy, v. 37, n. 7, p. 471-472, 2010. ERNST, D. Global production networks and the changing geography of innovation systems. Implications for developing countries. Economics of Innovation and New Technology, v. 11, n. 6, p. 497-523, 2002.

. Innovation offshoring: Asia's emerging role in global innovation networks. Honolulu: East-West Center, 2006.

. A new geography of knowledge in the eletronics industry? Asia's role in global innovation networks. Policy Studies, n. 54, 2009.

ERNST, D.; HART, D. M. Governing the Global Knowledge Economy: Mind the Gap!. Honolulu: East-West Center, 2008 (Working paper - Economics Serie, n. 93).

ERNST, D.; NAUGHTON, B. China's emerging industrial economy: insights from the IT industry. In: MCNALLY, C. A. (Ed.). China's emergent political economy: capitalism in the dragons' liar. London/New York: Routledge, 2008, p. 39-59.

EUN, J. H.; LEE, K.; WU, G. Explaining the. Research Policy, v. 35, n. 9, p. 1329-1346, 2006.

EVENSON, R. E.; GOLLIN, D. Assessing the impact of the Green Revolution, 1960 to 2000. Science, v. 300, n. 5620, p. 758, 2003.

EZZRARI, A.; VERME, P. A multiple correspondence analysis approach to the measurement of multidimensional poverty in Morocco, 2001-2007. Washington DC: The World Bank, 2012 (Working Paper Series, 6087).

FIGUEIREDO, P. N. The role of dual embeddedness in the innovative performance of MNE subsidiaries: evidence from Brazil. Journal of Management Studies, n. 48, p. 417440, 2011.

FREEMAN, C. Technology policy and economic performance. London: Pinter Publishers, 1988.

GOMPERS, P. A.; LERNER, J. The money of invention: how venture capital creates new wealth. Boston: Harvard Business Press, 2001.

GREENACRE, M. Correspondence analysis. Encyclopedia of Statistics in Behavioral Science. London: John Wiley \& Sons Ltd., 2005.

GREENE, W. Econometric analysis. Upper Sadlle River: Prentice Hall, 2003.

HENDERSON, J.; DICKEN, P.; HESS, M.; COE, N. YEUNG, H. W. Global production networks and the analysis of economic development. Review of International Political Economy, v. 9, n. 3, p. 436-464, 2002. 
HAGEDOORN, J. Inter-firm R\&D partnerships: an overview of major trends and patterns since 1960. Research Policy, v. 31, n. 4, p. 477-492, 2002.

INGINEUS. Patterns of knowledge accumulation, institutional frameworks and insertion in GINS in successful sub-national regions. 2011a. Available at: <http://www.feemdeveloper.net/ UserFiles/INGINEUS_D4.1.pdf>. Access: 03 Jan. 2013.

. Methodology report. complete standardised data set containing all the information collected in all countries. 2011b. Available at: <http://www.feemdeveloper.net/UserFiles/ INGINEUS_D2.2_MethodologyReport(1).pdf>. Access: 01 Mar. 2013

Complete standardised data set. 2011c. Available at: <http://www.ingineus.eu/ UserFiles/INGINEUS_D2.2_Fulldatasetandcodes_VER2.zip>. Access: 20 Dec. 2011.

KLEVORICK, A. K.; LEVIN, R. C.; NELSON, R. R.; WINTER, S. G. On the sources and significance of interindustry differences in technological opportunities. Research Policy, v. 24, n. 2, p. 185-205, 1995.

KRUSS, G.; ADEOTI, J.; NABUDERE, D. Universities and knowledge-based development in sub-Saharan Africa: comparing university-firm interaction in Nigeria, Uganda and South Africa. The Journal of Development Studies, v. 48, n. 4, p. 516-530, 2012.

KUEMMERLE, W. Building effective R\&D capabilities abroad. Harvard Business Review, n. 75, p. 61-72, 1997.

LE ROUX, B.; ROUANET, H. Multiple correspondence analysis. Los Angeles: Sage, 2010.

LEE, K.; JOSEPH, K.; ABRAHAM, V.; EUN, J. H.; WU, G.; WANG, Y. Promoting effective modes of university-industry interactions and their evolution for economic catch up in Asia. A Research Report for IDRC. Seoul: East Asia Institute. 2009.

LEVY, R.; ROUX, P.; WOLFF, S. An analysis of science-industry collaborative patterns in a large European University. The Journal of Technology Transfer, v. 34, n. 1, p. 1-23, 2009. Available at: <http://EconPapers.repec.org/RePEc:kap:jtecht:v:34:y:2009:i:1:p:1-23>.

LORENZ, E. Organisational innovation, governance structure and innovative capacity in British and French industry. DRUID, Copenhagen Business School, Department of Industrial Economics and Strategy/Aalborg University, Department of Business Studies, 1999 (DRUID Working Papers, n. 99-1). Available at: <http://EconPapers.repec.org/ RePEc:aal:abbswp:99-1>.

LUNDVALL, B-Å. Innovation as an interactive process - from user-producer interaction to national systems of innovation. In: DOSI, G.; FREEMAN, C.; NELSON, R.; SILVERBERG, G.; SOETE, L. (Eds.). Technical change and economic theory. London: Pinter, 1988, p. 349-367. 
MANSFIELD, E.; LEE, J.-Y. The modern university: contributor to industrial innovation and recipient of industrial R\&D support. Research Policy, v. 25, n. 7, p. 1047-1058, 1996. NARIN, F; HAMILTON, K. S.; OLIVASTRO, D. The increasing linkage between US technology and public science. Research Policy, v. 26, n. 3, p. 317-330, 1997.

NARULA, R.; GUIMÓN, J. The R\&D activity of multinational enterprises in peripheral economies: evidence from the EU new member states. Maastricht: UNU-MERIT, 2010.

NELSON, R. R. National innovation systems: a comparative analysis. Oxford: Oxford University Press, 1993.

NELSON, R. R.; WRIGHT, G. The rise and fall of American technological leadership: the postwar era in historical perspective. Journal of Economic Literature, v. 30, n. 4, p. 1931 1964, 1992.

OECD. Open innovation in global networks. Paris: OECD, 2008.

OSTRY, S.; NELSON, R. R. Techno-nationalism and techno-globalism: conflict and cooperation. Washington: The Brookings Institution, 1995.

PATEL, P. Localised production of technology for global markets. Cambridge Journal of Economics, v. 19, n. 1, p. 141-153, 1995.

PAVITT, K. What makes basic research economically useful? Research Policy, v. 20, n. 2, p. 109-119, 1991.

PRAGER, D. J.; OMENN, G. S. Research, innovation, and university-industry linkages. Science, v. 207, n. 4429, p. 379, 1980.

SUZIGAN, W.; RAPINI, M.; ALBUQUERQUE, E. A changing role for universities in the periphery. Belo Horizonte: Cedeplar-UFMG, 2011 (Textos para discussão, 420).

TETHER, B.; TAJAR, A. The organisational-cooperation mode of innovation and its prominence amongst European service firms. Research Policy, v. 37, n. 4, p. 720-739, 2008.

THE ECONOMIST INTELLIGENCE UNIT. Sharing the idea: the emergence of Global Innovation Networks. London: The Economist, 2007.

THURSBY, J.; THURSBY, M. Here or there? A survey of factors in multinational R\&D location. 2006Available at: <http://www.nap.edu/catalog.php?record_id=11675>. Access: 01 Mar. 2013.

UNCTAD. World investment report 2005 - Transnational corporations and the internationalization of $R \& D$. Geneva: United Nation Conference on Trade and Development, 2005. 


\section{Appendix}

TABLE 1

Descriptive statistics for the variables used in MCA test

\begin{tabular}{l|c|c|c|c|c}
\hline \multicolumn{1}{c|}{ Variable } & Obs. & Mean & Std. dev. & Min. & Max. \\
\hline Type of enterprise & 1074 & 1,48 & 0,71 & 1 & 3 \\
R\&D & 1077 & 2,11 & 0,99 & 1 & 3 \\
Source of technology & 1028 & 1,89 & 1,23 & 1 & 5 \\
Internationalization & 1029 & 1,59 & 0,91 & 1 & 3 \\
Formal int. foreign univ. & 1215 & 1,30 & 0,71 & 1 & 3 \\
Informal int. foreign univ. & 1215 & 1,12 & 0,48 & 1 & 3 \\
Interaction local univ. & 1215 & 1,62 & 0,93 & 1 & 3 \\
\hline
\end{tabular}

Source: Ingineus (2011c).

TABLE 2

Correlation table for the variables used in the econometric test

\begin{tabular}{l|c|c|c|c|c}
\hline & $\begin{array}{c}\text { Interaction } \\
\text { foreign } \\
\text { institutions }\end{array}$ & MNC & $\begin{array}{c}\text { Internationali- } \\
\text { zation }\end{array}$ & $\mathbf{R} \& \mathbf{D}$ & $\begin{array}{c}\text { Local } \\
\text { interactions }\end{array}$ \\
\hline $\begin{array}{l}\text { Interaction foreign } \\
\text { institutions }\end{array}$ & 1.00 & & & & \\
MNC & 0.20 & 1.00 & & & \\
Internationalization & 0.36 & 0.29 & 1.00 & & \\
R\&D & 0.19 & 0.23 & 0.26 & 1.00 & \\
Local interactions & 0.33 & 0.04 & 0.22 & 0.18 & 1.00 \\
\hline
\end{tabular}

Source: Ingineus (2011c). 
